\title{
Climate-driven changes in air quality over Europe by the end of the 21st century, with special reference to Portugal
}

\author{
A. Carvalho ${ }^{a, *}$, A. Monteiro $^{a}$, S. Solman ${ }^{b}$, A.I. Miranda ${ }^{a}$, C. Borrego ${ }^{a}$ \\ ${ }^{a}$ CESAM \& Department of Environment and Planning, University of Aveiro, 3810-193 Aveiro, Portugal \\ ${ }^{\mathrm{b}}$ CIMA, Intendente Guiraldes 2160, Ciudad Universitaria, Pabellón II, $2^{\circ}$ Piso, C1428EGA Buenos Aires, Argentina
}

\section{A R T I C L E I N F O}

Published on line 31 May 2010

\section{Keywords:}

Air quality modelling

Regional climate change

Meteorological fields

Ozone

Particulate matter

\begin{abstract}
A B S T R A C T
Climate change alone may deeply impact air quality levels in the atmosphere because the changes in the meteorological conditions will induce changes on the transport, dispersion and transformation of air pollutants. The aim of this work was to evaluate the impact of climate change on the air quality over Europe and Portugal, using a reference year (year 1990) and a IPCC SRES A2 year (year 2100). The Hadley Centre global atmospheric circulation model (HadAM3P) was used to provide results for these two climatic scenarios, which were then used as synoptic forcing for the MM5-CHIMERE air quality modelling system. In order to assess the contribution of future climate change on $\mathrm{O}_{3}$ and $\mathrm{PM}$ concentrations, no changes in regional emissions were assumed and only climate change forcing was considered. The modelling results suggest that the $\mathrm{O}_{3}$ monthly mean levels in the atmosphere may increase almost $50 \mu \mathrm{g} \mathrm{m}^{-3}$ across Europe in July under the IPCC SRES A2 scenario. In Portugal, this increase may reach $20 \mu \mathrm{g} \mathrm{m}^{-3}$. The changes of PM10 monthly average values over Europe will depend on the region. The increase in PM10 concentrations during specific months could be explained by the average reduction of the boundary layer height and wind speed.
\end{abstract}

(C) 2010 Elsevier Ltd. All rights reserved.

\section{Introduction}

Anthropogenic emissions are a leading cause of climate change; however, climate change is also impacting the concentration and distribution of pollutants in the atmosphere. This feedback mechanism forms a nonlinear loop of relationships between emissions and chemical and physical processes in the atmosphere. Among these atmospheric chemical species, ozone $\left(\mathrm{O}_{3}\right)$ is of primary concern because of its power as a tropospheric oxidant and its greenhouse effects at global scale (Gauss et al., 2006). $\mathrm{O}_{3}$ is an extremely reactive chemical that has also been shown to have harmful effects on human health, crop production and natural areas (Keyes et al., 2001). As a result of the increase in ozone's precursor emissions, namely nitrogen oxides, tropospheric ozone concentrations have increased by about 35\% since preindustrial period (IPCC, 2001).

Particulate matter (PM) is another important air pollutant closely connected to adverse air quality problems (Monteiro et al., 2007). High levels of PM are associated with adverse health effects, ecosystem damage, and degraded visibility (Goswami et al., 2002; Anderson et al., 2004). According to the most recent report on PM transboundary pollution in Europe (EMEP, 2007), 50\% of monitoring sites reported exceedances of the annual mean limit value of PM10 (particles with an aerodynamic equivalent diameter smaller than $10 \mu \mathrm{m}$ ). These high PM10, and also PM2.5 (aerodynamic equivalent diameter smaller than $2.5 \mu \mathrm{m}$ ), levels can be partly explained by an emission increasing trend, and by specific meteorological conditions, like suppression of pollutant dispersion into the

\footnotetext{
* Corresponding author. Tel.: +351 234370349; fax: +351234 370309 .

E-mail address: avc@ua.pt (A. Carvalho). 
stable atmosphere or smaller wet deposition due to less precipitation (EMEP, 2007). Moreover, secondary particles also contribute to the higher levels of PM10 and PM2.5 registered in Europe (Pio et al., 2007). Particulate matter may also play an important role in climate change. Some types of PM may heat the atmosphere, while other particles may have a cooling effect (IPCC, 2007). The impact of climate change on air quality, namely on $\mathrm{O}_{3}$ and PM10 levels, can be a serious threat to sustainable development (Semazzi, 2003), particularly with regard to human health and environmental resources. The majority of the work on climate/chemistry interactions has taken place at the global scale, namely through the application of global chemical transport models (CTMs) and climate chemistry models (CCMs). Hauglustaine et al. (2005) suggest that global mean $\mathrm{O}_{3}$ could increase more than $30 \mathrm{ppb}$ over northern hemisphere during the summer of 21st century as a direct consequence of enhanced anthropogenic and biogenic emissions of $\mathrm{O}_{3}$ precursors like nitrogen oxides (NOx) and volatile organic compounds (VOCs). An evaluation of the highemissions IPCC SRES A2 emissions scenario showed global July mean surface $\mathrm{O}_{3}$ increases of about 5 ppb by the year 2030, and 20 ppb by 2100 (Prather et al., 2003). Based on the ensemble mean of 26 global atmospheric chemistry-transport models, Dentener et al. (2006) predicted that by 2030 global surface ozone may increase globally by $4.3 \pm 2.2 \mathrm{ppb}$ for the IPCC SRES A2 scenario. The same study points out that the SRES A2 scenario, which induces higher pollution levels, would compromise the attainment of any existing air quality standard in most industrialized parts of the world by 2030 . Under the SRES A2 scenario, Szopa et al. (2006) estimated that by 2030 , the $\mathrm{O}_{3}$ levels in July may increase up to 5 ppb across Europe, due to combined effects of local emission changes added to background $\mathrm{O}_{3}$ changes. Nevertheless, it should be noticed that this SRES A2 scenario is considered to be a pessimistic one (Dentener et al., 2006).

Few studies have been conducted at a regional scale. Hogrefe et al. (2004) present the results for the Eastern United States via downscaling from a global to regional scale. The authors analysed the impacts of regional climate change on air quality and concluded from a simulation of five summers in the 2020s, 2050s and 2080s that the average daily summertime maximum 8-h ozone concentrations will increase by 2.7, 4.2 and $5.0 \mathrm{ppb}$, respectively. Zlatev (2007) and Langner et al. (2005) present the first regional scale studies for Europe. These studies only considered the impacts of climate change on air quality, while keeping the emissions rate constant. Both studies point to an increase in photochemical production in future climatic scenarios. In Portugal, this topic was addressed through the application of a cascade of models, from global to regional scale, to selected episodic situations (Miranda et al., 2005). The air quality model, at the end of this modelling cascade, was applied to a 6-days period in 1990 and 2050 climates. These periods were chosen based on the assumption that photochemical production is enhanced when consecutive daily average temperature is above $25^{\circ} \mathrm{C}$. The results indicate an increase of the number of days that are favourable for photochemical production in a future climatic scenario and an increase in average ozone concentrations and variability.

To study the impact of climate change on regional air quality, namely on concentrations of $\mathrm{O}_{3}$ and PM, climatic scenarios with high temporal and spatial resolution are needed. These scenarios are mainly needed to demonstrate the importance of meteorological variables on the ozone chemical mechanism and on PM dispersion and removal from the atmosphere, and to show the regional patterns of ozone precursor emissions. With regard to the impact assessment of such studies, the downscaling of large-scale climatic patterns to the regional scale is essential (Mearns et al., 2003). In this study, a limited area of the globe is represented at a very high resolution with a mesoscale model. The effect of a changing climate on the air quality over Europe and over Portugal was assessed through the application of the MM5/CHIMERE (Dudhia, 1993; Schmidt et al., 2001) air quality modelling system.

\section{Methodology}

The air quality modelling application was performed for reference and future climatic scenarios by dynamic downscaling using HadAM3P outputs (Jones et al., 2005), as initial and boundary conditions to the meteorological MM5 model. The HadAM3P simulations were performed for the reference and the IPCC SRES A2 climate scenario. The global IPCC SRES A2 scenario family represents a differentiated world, in terms of social and political structures. This scenario is also characterized by a continuously increasing of the global population that reaches 15.1 billion by 2100 . This scenario is considered to be the highest emission scenario with carbon emissions increase of $1862 \mathrm{Gt}$ from 1990 to 2100. Concerning methane $\left(\mathrm{CH}_{4}\right)$, carbon monoxide $(\mathrm{CO})$ and nitrogen oxides (NOx), the A2 scenario considers increases in 2100 that reach $889 \mathrm{Mt}$ of $\mathrm{CH}_{4} /$ year, $2326 \mathrm{Mt}$ of $\mathrm{CO} /$ year and $109 \mathrm{Mt}$ of N/year. Under the A2 scenario, the $\mathrm{CO}_{2}$ concentrations would reach 850 ppm by 2100 . In this sense, we are assessing the worst scenario with regard to air quality changes.

\subsection{Air quality modelling system}

The air quality modelling system is based on the chemistrytransport model CHIMERE (Schmidt et al., 2001; Bessagnet et al., 2004), forced by the mesoscale model MM5 (Grell et al., 1994).

The MM5 model has been used worldwide in several regional climate studies (Leung and Ghan, 1999; Boo et al., 2004; Leung et al., 2004; Van Dijck et al., 2005), and CHIMERE has also been applied in climate change impact assessment studies at the European level (Giorgi and Meleux, 2007; Meleux et al., 2007; Szopa et al., 2006). The MM5/CHIMERE modelling system has been also widely applied and validated in several air quality studies in Portugal (Monteiro et al., 2005, 2007; Borrego et al., 2008), showing quality indicators within the range found in several model evaluation studies using different chemical transport models (Vautard et al., 2007; Stern et al., 2008).

The MM5 mesoscale model is a nonhydrostatic, vertical sigma-coordinate model designed to simulate mesoscale atmospheric circulations. MM5 has multiple nesting capabilities, four-dimensional data assimilation (FDDA) availability, and a large variety of physics options. The selected MM5 
physical options were based on validation and sensitivity studies previously performed in Portugal (Aquilina et al., 2005; Carvalho et al., 2006) and the Iberian Peninsula (Fernández et al., 2007). The MM5 model generates several meteorological fields required by the CHIMERE model, such as wind, temperature, water vapour mixing ratio, cloud liquid water content, $2 \mathrm{~m}$ temperature, surface heat, moisture fluxes and precipitation.

CHIMERE is a tri-dimensional chemistry-transport model, based on the integration of the continuity equation for the concentrations of several chemical species in each cell of a given grid. It was developed for simulating gas-phase chemistry (Schmidt et al., 2001), and aerosol formation, transport and deposition (Bessagnet et al., 2004; Vautard et al., 2005) at regional and urban scales. The meteorological input variables driven by the MM5 model are linearly interpolated into the CHIMERE grid. In addition to the meteorological input, the CHIMERE model needs boundary and initial conditions, emission data, and the land use and topography characterization. It requires hourly spatially resolved emissions for the main anthropogenic gas and aerosol species. The non-methane volatile organic compounds (NMVOCs) are disaggregated into 227 individuals. The methodology for biogenic emissions of isoprene and terpenes is described in Schmidt et al. (2001). The land use database comes from the Global Land Cover Facility (Hansen et al., 2000) and provides the grid cell coverage of coniferous and broadleaf forests. The Stohl et al. (1996) methodology is used for biogenic emissions of nitrogen monoxide (NO) from fertilized soils. The model simulates the concentration of 44 gaseous species and six aerosol chemical compounds. The chemical mechanism (MELCHIOR) is adapted from the original EMEP mechanism. Photolytic rates are attenuated using liquid water or relative humidity. The aerosol model accounts for both inorganic and organic species, of primary or secondary origin, such as primary particulate matter (PPM), sulfates, nitrates, ammonium, secondary organic species (SOA) and water. The population of aerosol particles is represented by a sectional formulation, assuming discrete aerosol size sections and considering the particles of a given section to be internally mixed. Eight diameter bins ranging between $10 \mathrm{~nm}$ and $40 \mu \mathrm{m}$, with a geometric increase of bin bounds, are used. The ISORROPIA equilibrium model (Nenes et al., 1999) is used to calculate concentrations at equilibrium for inorganic aerosols composed of sulfate, nitrate, ammonium and water. Dynamical processes influencing aerosol population are also described. Aerosols can be removed by dry deposition and wet removal (Guelle et al., 1998).

\subsection{Air quality modelling application}

In order to assess the impact of climate change on air quality, the MM5/CHIMERE modelling system was forced by the Hadley Centre global atmospheric circulation model HadAM3P (Jones et al., 2005). The Hadley Centre's HadAM3P (2.5 latitude by $2.5^{\circ}$ longitude resolution) is a successor version of the HadAM3H model (Pope et al., 2000; Jones et al., 2001), which is an improved version of the atmospheric component of the latest Hadley Centre coupled Atmosphere-Ocean General Circulation Model (AOGCM), HadCM3 (Gordon et al., 2000). The sea surface temperatures (SSTs) used in the HadAM3P reference simulation were taken from a gridded data set of monthly mean observations covering the period from 1960 to 1990 (Jones et al., 2003). The climate change simulation used SSTs from an existing HadCM3 simulation and applied the obtained monthly anomalies to 30-year average grid monthly mean observed climatology.

Anagnostopoulou et al. (2008) analysed the performance of the HadAM3P simulations against the NCEP/NCAR reanalysis data (Kalnay et al., 1996) across the Mediterranean region. The obtained results provide some support for using the HadAM3P outputs as initial and boundary conditions for regional simulations.

Outputs, for Europe and Portugal, from the HadAM3P simulations for a reference year (1961-1990) and an IPCC SRES A2 climate scenario year (2071-2100) were used by dynamic downscaling as initial and boundary conditions for the MM5 model. The MM5 model requires initial and time evolving boundary conditions for wind components, temperature, geopotential height, relative humidity, surface pressure and the specification of SSTs.

The integration between the HadAM3P outputs and the MM5 model was obtained through a programming stage that was implemented in order to convert, interpolate and generate the pressure levels and the data formats requirements needed for the MM5 simulations. The downscaling of the HadAM3 model outputs to the MM5 model has already been carried out for regional climate change simulations over South America (Solman et al., 2007).

The MM5 and the CHIMERE models were first applied at the European scale and then to Portugal using the same physics and a simple one-way nesting technique. The European domain covers an area from $14^{\circ} \mathrm{W}$ to $25^{\circ} \mathrm{E}$ and $35^{\circ} \mathrm{N}$ to $58^{\circ} \mathrm{N}$. The simulation domain for Portugal encompasses from $9.5^{\circ} \mathrm{W}$ to $6^{\circ} \mathrm{W}$ and $37^{\circ} \mathrm{N}$ to $42.5^{\circ} \mathrm{N}$. The spatial resolutions used for both MM5 and CHIMERE models, together with other simulation characteristics are summarized in Table 1.

The vertical resolution of the CHIMERE model consists of eight vertical layers of various thicknesses extending from

Table 1 - MM5 and CHIMERE simulation characteristics.

\begin{tabular}{|c|c|c|}
\hline & $\begin{array}{c}\text { European } \\
\text { domain (D1) }\end{array}$ & $\begin{array}{l}\text { Portuguese } \\
\text { domain (D2) }\end{array}$ \\
\hline \multicolumn{3}{|l|}{ MM5 } \\
\hline Dimensions $(X, Y)$ & $96 \times 81$ cells & $73 \times 109$ cells \\
\hline Horizontal resolution & $54 \mathrm{~km}$ & $9 \mathrm{~km}$ \\
\hline Vertical resolution & 25 sigma levels & 25 sigma levels \\
\hline \multirow[t]{4}{*}{ Physics } & MRF PBL scheme & MRF PBL scheme \\
\hline & $\begin{array}{l}\text { RRTM radiation } \\
\text { scheme }\end{array}$ & $\begin{array}{l}\text { RRTM radiation } \\
\text { scheme }\end{array}$ \\
\hline & $\begin{array}{l}\text { Grell cumulus } \\
\text { scheme }\end{array}$ & $\begin{array}{l}\text { Grell cumulus } \\
\text { scheme }\end{array}$ \\
\hline & $\begin{array}{l}\text { Simple ice } \\
\text { moisture } \\
\text { scheme }\end{array}$ & $\begin{array}{l}\text { Graupel moisture } \\
\text { scheme }\end{array}$ \\
\hline \multicolumn{3}{|l|}{ CHIMERE } \\
\hline Dimensions $(\mathrm{X}, \mathrm{Y})$ & $47 \times 79$ cells & $29 \times 58$ cells \\
\hline Horizontal resolution & $50 \mathrm{~km}$ & $10 \mathrm{~km}$ \\
\hline Vertical resolution & 8 levels & 8 levels \\
\hline Chemical mechanism & Melchior2 & Melchior2 \\
\hline
\end{tabular}


ground to $500 \mathrm{hPa}$, with the first layer at $50 \mathrm{~m}$. The lateral and top boundaries for the large-scale run were obtained from the LMDz-INCA (gas species) (Hauglustaine et al., 2005) and GOCART (aerosols) (Ginoux et al., 2001) global chemistrytransport models. Transport of Saharan dust from the GOCART boundary conditions, as well as within-domain erosion, are considered using the formulation of Vautard et al. (2005). Resuspension of material other than soil particles is not taken into account. For the Portugal domain, boundary conditions are obtained via large-scale simulation.

For the large-scale simulation (Europe), the hourly anthropogenic emissions for nitrogen oxides (NOx), carbon monoxide (CO), sulphur dioxide $\left(\mathrm{SO}_{2}\right)$, non-methane volatile organic components (NMVOC) and ammonia $\left(\mathrm{NH}_{3}\right)$ gas-phase species and PM2.5 and PM10 are provided by the European Monitoring and Evaluation Programme (EMEP) (Vestreng, 2003) with a spatial resolution of $50 \mathrm{~km}$, and for the base year 2003. There is no chemical speciation for PM emissions.

For the fine scale Portuguese domain, the 2003 national inventory was used. This national inventory takes into account annual emissions from line sources (streets and highways), area sources (industrial and residential combustion, solvents and others) and large point sources. These annual emission data for the activity of each pollutant were spatially disaggregated in order to obtain the resolution required for the Portuguese domain simulation. The disaggregation occurs in two steps. First, emissions are estimated at a municipality level using adequate statistical indicators for each pollutant activity (types of fuel consumption) and then distributed according to the population density (Monteiro et al., 2007). For large point sources, emissions were obtained directly from the available monitoring data of each industrial plant. Emissions for road transport are based on real fluxes, measured average speed and COPERT III emission factors, following a "bottom-up approach" (Monteiro et al., 2007). The NMVOC speciation into appropriate classes for the chemical mechanism is carried out according to a standard methodology (Middleton et al., 1990). The PM emissions are partitioned into three size bins: PM2.5, particles between PM2.5 and PM10 and particles larger than PM10. Simpson et al. (1999) methodology was adopted to calculate biogenic emissions within the CHIMERE model. Time disaggregation was obtained by application of monthly, weekly and finally hourly profiles from the University of Stuttgart (GENEMIS, 1994).

To evaluate the influence of climate change on air quality, the anthropogenic emissions were kept constant (to the year 2003) in the simulations for the future climate and were not scaled in accordance with the IPCC SRES A2 scenario. The air quality simulations assumed no changes neither in the regional anthropogenic emissions of the chemical species primarily involved in the chemical reactions of ozone formation and destruction nor in the global ozone background, and only accounted for climate changes. In this sense, the inclusion of effects produced by the climate scenario, such as modifications in vertical distribution of gaseous and aerosol compounds, which in turn produce modifications in the radiative processes and consequently in the chemical reactions occurring in the atmosphere were not taken into account. This idealized regional model simulation provides insight into the contribution of possible future climate changes on the 3D distribution of ozone and particulate matter concentrations.

The MM5/CHIMERE simulations were conducted from May 1st to October 30th for the reference year (1990) and for the future scenario year (2100). The highest photochemical activity is found in this period. Both simulations had the same chemical boundary conditions. Following this methodology, it is possible to analyse the changes only caused by climate change over both studied domains.

\section{Results and discussion}

To correctly assess the climate change impacts on future air quality patterns, firstly we will briefly discuss the global model HadAM3P and the MM5 ability to simulate the present climate.

Anagnostopoulou et al. (2008) concluded that the HadAM3P accurately reproduces the seasonal $500 \mathrm{hPa}$ geopotential heights, whereas their seasonal variability is underestimated. The $500 \mathrm{hPa}$ height reflects a broad range of meteorological influences on air quality. The frequency of occurrence of 14 weather types has also been assessed. The results indicate that the HadAM3P is able to capture the mean patterns of the circulation types. The obtained results give some confidence to use the HadAM3P outputs as initial and boundary conditions for regional simulations. In the scope of an air quality assessment it is important that the global model gives an accurate representation of the large-scale flow fields for the region of interest.

The dynamical downscaling of the HadAM3P outputs to the MM5 model has already been attempted by Solman et al. (2007) over southern South America. The authors concluded that the observed regional patterns of surface air temperatures (means, maxima, and minima) were well reproduced. The broad spatial pattern of precipitation and its seasonal evolution was also well captured by the model. Overall, it was concluded that the MM5 model is capable of reproducing the main regional patterns and seasonal cycle of the surface variables.

Concerning this study, Fig. 1 presents the average temperature field over Europe between May and October based on the Climatic Research Unit observed dataset (New et al., 2002) (Fig. 1a) and simulated by the MM5 model for the year 1990 (Fig. 1b).

According to Fig. 1b, the MM5 model is capable of simulating realist average temperature and the obtained results are representative of the temperature spatial patterns over Europe (Fig. 1a). The average temperature field from May to October ranges between $-4{ }^{\circ} \mathrm{C}$ in the mountainous regions and $28^{\circ} \mathrm{C}$ in the southern part of the domain (Fig. 1b). The MM5 model tends to underestimate the temperature over the Mediterranean sea. The obtained results give some confidence to the projections simulated with the MM5 model for the future climate scenario.

In the following analysis, we present the main results regarding the climate change impacts on $\mathrm{O}_{3}$ and PM10 concentrations for Europe and Portugal. All the spatial concentration patterns presented in this section are exhibited as differences between the future and the reference scenarios. In addition, the monthly patterns will only be presented for the months where the changes were highest. 

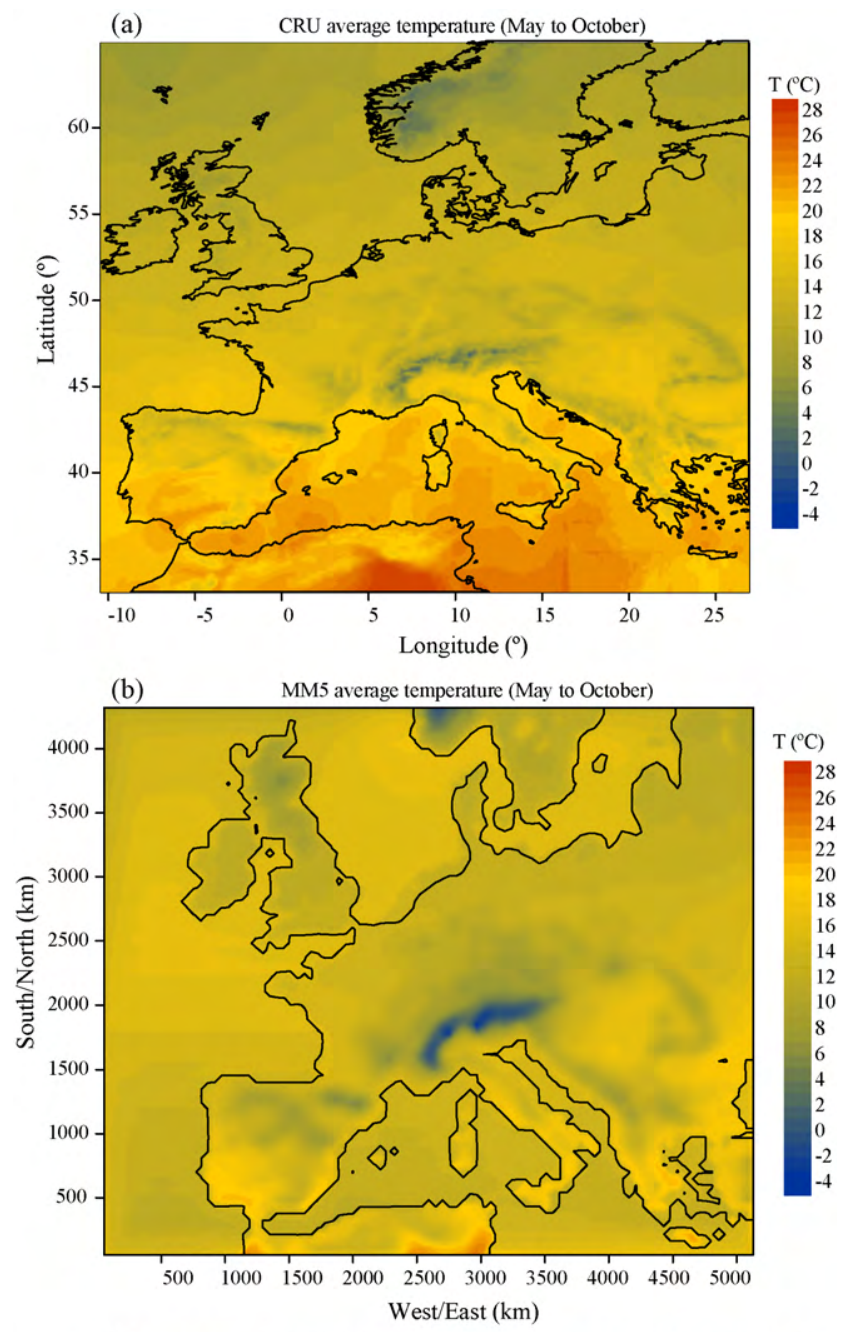

(c) MM5 simulated changes on average temperature between May and October

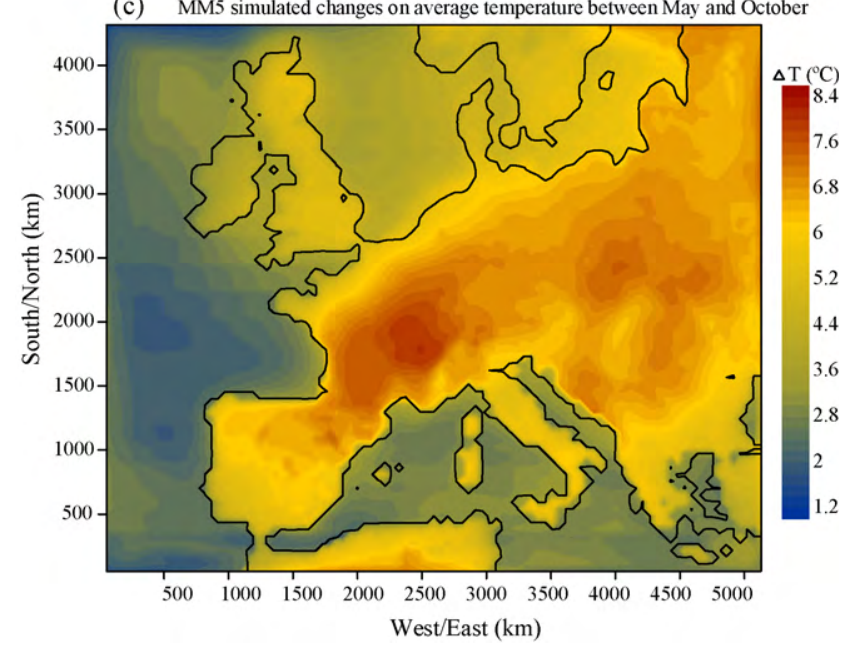

Fig. 1 - Average surface temperature $\left({ }^{\circ} \mathrm{C}\right)$ from May to October based on the (a) CRU dataset and on the (b) MM5 simulations for the year 1990; (c) MM5 simulated differences on the average temperature from May to October between 2100 and 1990.

\section{1. $\mathrm{O}_{3}$ and PM10 concentrations over Europe}

Fig. 2 shows the MM5/CHIMERE European results regarding the monthly mean surface $\mathrm{O}_{3}$ and $\mathrm{PM}_{10}$ concentration changes from July to October between the future and reference climates. Because the anthropogenic emissions have not been scaled in accordance to the SRES A2 scenario, the obtained changes in $\mathrm{O}_{3}$ and PM10 surface levels are only caused by climate change.

The $\mathrm{O}_{3}$ concentration changes obtained with the modelling system show that the highest differentials are observed over central Europe with increases of almost $50 \mu \mathrm{g} \mathrm{m}^{-3}$ in July. Over the ocean, where destruction caused by water vapour prevails, $\mathrm{O}_{3}$ decreases by up to $20 \mu \mathrm{g} \mathrm{m}^{-3}$. These results are in the same range of magnitude of those found by Hauglustaine et al. (2005). On the other hand, Dentener et al. (2006) concluded that by 2030 climate change is expected to modify the global mean ozone levels by $-0.8 \pm 0.6 \mathrm{ppb}$ (over the Organisation for Economic Co-operation and Development - OECD - Europe these changes are $-0.4 \pm 0.7 \mathrm{ppb}$ ), with larger decreases over sea than over land. The same authors highlight that, climatedriven increases in temperature and water vapour tend to decrease surface $\mathrm{O}_{3}$ in the cleanest regions, but tend to increase $\mathrm{O}_{3}$ in more polluted areas. In July, it is also possible to detect an increase of approximately $20 \mu \mathrm{g} \mathrm{m}^{-3}$ in the $\mathrm{O}_{3}$ levels over Galicia and the Gulf of Biscay, thus influencing the concentration of this pollutant in the north of Portugal. Meleux et al. (2007) also detected this pattern. This finding is explained by the largest temperature increases over Galicia, France and United Kingdom (Fig. 3) because, overall, ozone production increases with increased temperature (Sillman and Samson, 1995). The decrease in the height of the average boundary layer (BL) and average wind speed in July may also contribute to the ozone enhancements over Galicia (Fig. 3). In addition, the EMEP emissions grid (not shown) presents high levels of pollutants emitted in Galicia, mainly due to industrial combustion processes, which in a changing climatic scenario, may deeply impact the air quality in the region.

The simulated changes in the weather patterns (Fig. 3) are closely related to the nature of the changes in the large-sale circulation in the climate change simulation that provides the lateral boundary conditions to the MM5 model. For instance, in May (2007) for the future climate there is an increase in the atmospheric pressure in western and central Europe during summer, indicating a northward shift in the location of the Azores high. This same pattern has also been detected in our simulations. The changes in the mean sea level pressure (MSLP) field (not shown) indicate an increase in the pressure field over the northern part of the simulation domain and a decrease over southern Europe namely over the Iberian Peninsula. This circulation changes will impact the surface climate variables. In our study the simulated temperature changes, between May and October, almost reach $8.5^{\circ} \mathrm{C}$ over mid and southern Europe (Fig. 1c). These projections are in accordance to Rowell (2005) that predicted that in winter the largest warming occurs over eastern Europe, up to $7{ }^{\circ} \mathrm{C}$, and in summer, temperatures rise by $6-9^{\circ} \mathrm{C}$ south of about $50^{\circ} \mathrm{N}$.

August and September also register increases and decreases in $\mathrm{O}_{3}$ concentrations depending on the region. The increases in the $\mathrm{O}_{3}$ concentrations are not as high as in 

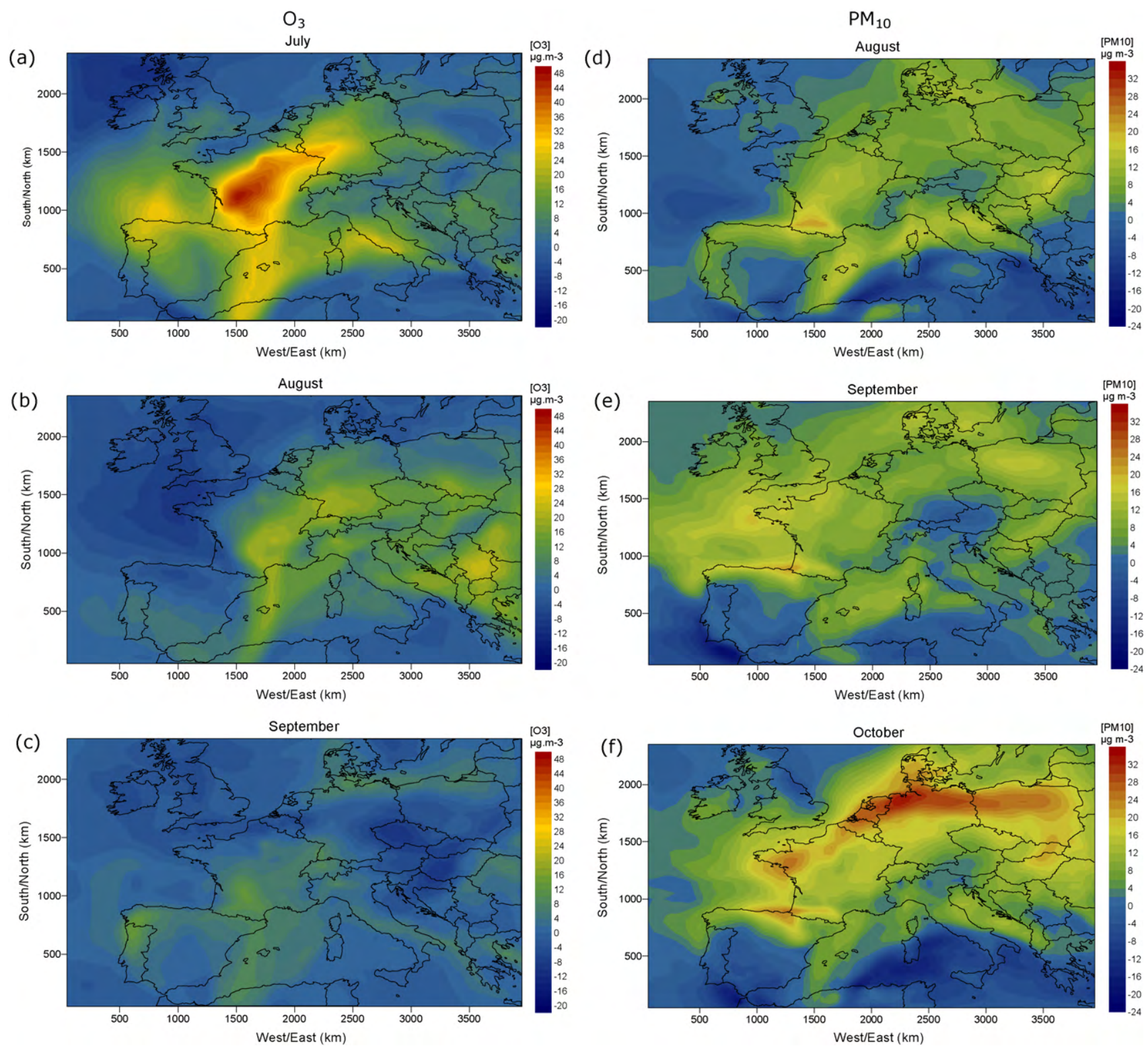

Fig. 2 - Monthly mean surface $\mathrm{O}_{3}$ and PM10 concentration changes $\left(\mu \mathrm{g} \mathrm{m}^{-3}\right)$ simulated across Europe, only considering climate change from July to October.

July, but reached almost $24 \mu \mathrm{g} \mathrm{m}^{-3}$ in August and $14 \mu \mathrm{g} \mathrm{m}^{-3}$ in September over central Europe. From July to September, the simulated decreases in the $\mathrm{O}_{3}$ concentrations reached $10 \mu \mathrm{g} \mathrm{m}^{-3}$ and were mainly detected over water except in September where decreases were predicted over Eastern Europe. Ozone is strongly positively correlated with high temperatures and solar radiation, as this enhances the photochemical conditions that lead to ozone formation (Comrie, 1996). In the eastern United States, high temperatures, large concentrations of water vapour, high solar radiation and stagnant conditions were the variables most correlated with high ozone levels (Vukovich and Sherwell, 2003). In the southwest United States, temperature and mixing height most strongly influenced ozone conditions (Wise and Comrie, 2005).

Concerning climate change, if the BL height is higher in the reference climate run, primary pollutants will be diluted and react under conditions with lower concentrations. If synoptic changes in the future scenario lead to altered BL heights, then the concentrations would change as well. However, the nonlinearity of the reactions generating the ozone will produce a different amount leading to other changes than just the percentage change in the BL height (Gustafson and Leung, 2007). Kunkel et al. (2007) reported that for the northeastern USA the mean and the 8-h maximum ozone increases in future climate are due to higher temperatures, lower cloudiness and higher biogenic emissions.

In addition, previous works have highlighted that the occurrence of high ozone episodes in Portugal is related to a strong positive anomaly of the MSLP field centred in the north of the Iberian Peninsula and weak negative anomaly over the Iberian Peninsula (Carvalho et al., 2010). In our study we have detected that this pattern will be intensified and thus an 

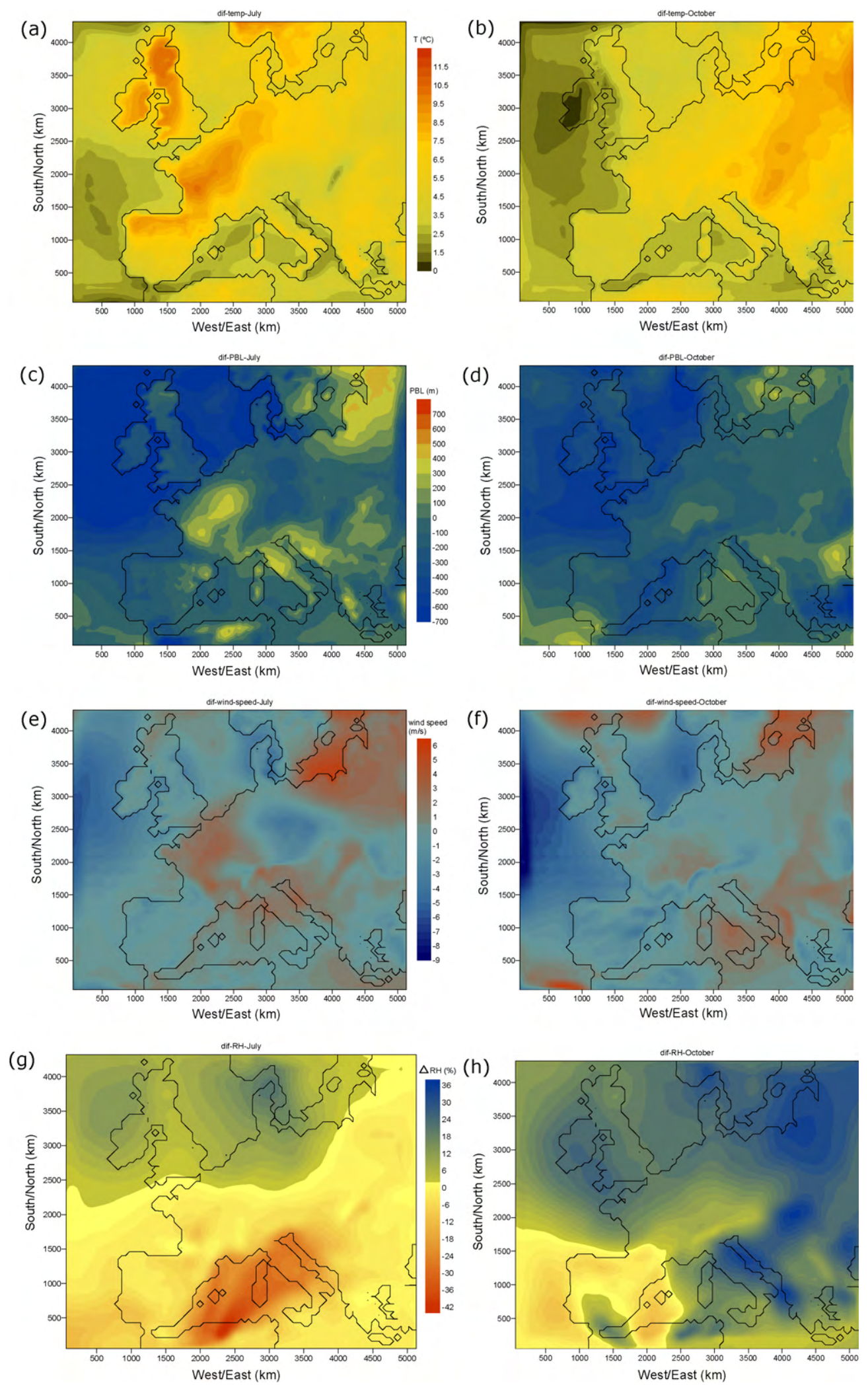

Fig. 3 - Monthly mean surface temperature $\left({ }^{\circ} \mathrm{C}\right)$, boundary layer height $(\mathrm{m})$, wind speed $\left(\mathrm{m} \mathrm{s}^{-1}\right)$ and relative humidity $(\%)$ differences between future and reference climates simulated with the MM5 model across Europe for July and October. 
increase in the ozone peak levels is expected under future climate.

The PM10 monthly average concentration values over Europe may register increases and decreases depending on the region and the month, as shown in Fig. 2. The registered increases are mainly located over the continental regions and the decreases over water or in its vicinity. For the month of October, where the highest changes are detected, the regions with higher increases on the PM10 levels also experience decreases in the BL height and increases in relative humidity between the reference and future climate (Fig. 3). Stagnant conditions are thought to be correlated with high PM concentrations, as they allow particulates to accumulate near the earth's surface (Wise and Comrie, 2005). Wind speed differences may also contribute to the PM10 change patterns. Although high wind speeds can increase ventilation, they can be correlated with high PM concentrations because they allow the resuspension of particles from the ground, as well as longrange transport of particulates between regions (Gustafson and Leung, 2007). This may only be true for specific regions of the world because phenomena like dispersion, resuspension, long-range transport and chemical transformations should all be considered in this analysis but the local and regional aspects might modify the relative weight of each one. In October, the MM5 simulation at the European scale points to an average decrease of the BL height and wind speed, which may be related to the increase of almost $32 \mu \mathrm{g} \mathrm{m}^{-3}$ in PM10 concentrations over Central Europe. In July, PM10 increases are also expected over the northern Iberian Peninsula and the Gulf of Biscay and a decrease in the average BL height and on the average wind speed may also contribute to these results.

Moreover, high PM concentrations are normally associated with dry conditions due to increased potential for resuspension of dust, soil, and other particles. In the southwestern United States, the moisture level, namely the relative humidity, is the strongest predictor of PM concentrations (Wise and Comrie, 2005).

\section{2. $\mathrm{O}_{3}$ and PM10 concentrations over Portugal}

Fig. 4 displays the monthly changes in $\mathrm{O}_{3}$ and PM10 mean concentrations caused by climate change over Portugal.

Caused solely by climate change, the PM10 concentrations increase almost $15 \mu \mathrm{g} \mathrm{m}^{-3}$ in August over the North coastal region. This situation may be closely related to an average decrease in BL height (not shown). The months of September and October register the highest increases in PM10 values reaching 30 and $26 \mu \mathrm{g} \mathrm{m}^{-3}$, respectively. For both months, the $\mathrm{BL}$ average height registers a decrease from the reference to the future climate. September shows an increase in the $\mathrm{RH}$ mean field (not shown) but October registers a decrease in this field (Fig. 5).

In summary, the monthly average concentrations revealed that climate change may deeply impact the PM10 levels in the atmosphere. The Porto region is the most affected in terms of PM10 increases. This region is already facing specific air quality problems mostly related to the high levels of PM10 that are measured at the monitoring network (Monteiro et al., 2007).

It is important to stress that this analysis highlighted the distinct projected monthly averaged changes in the PM10 field
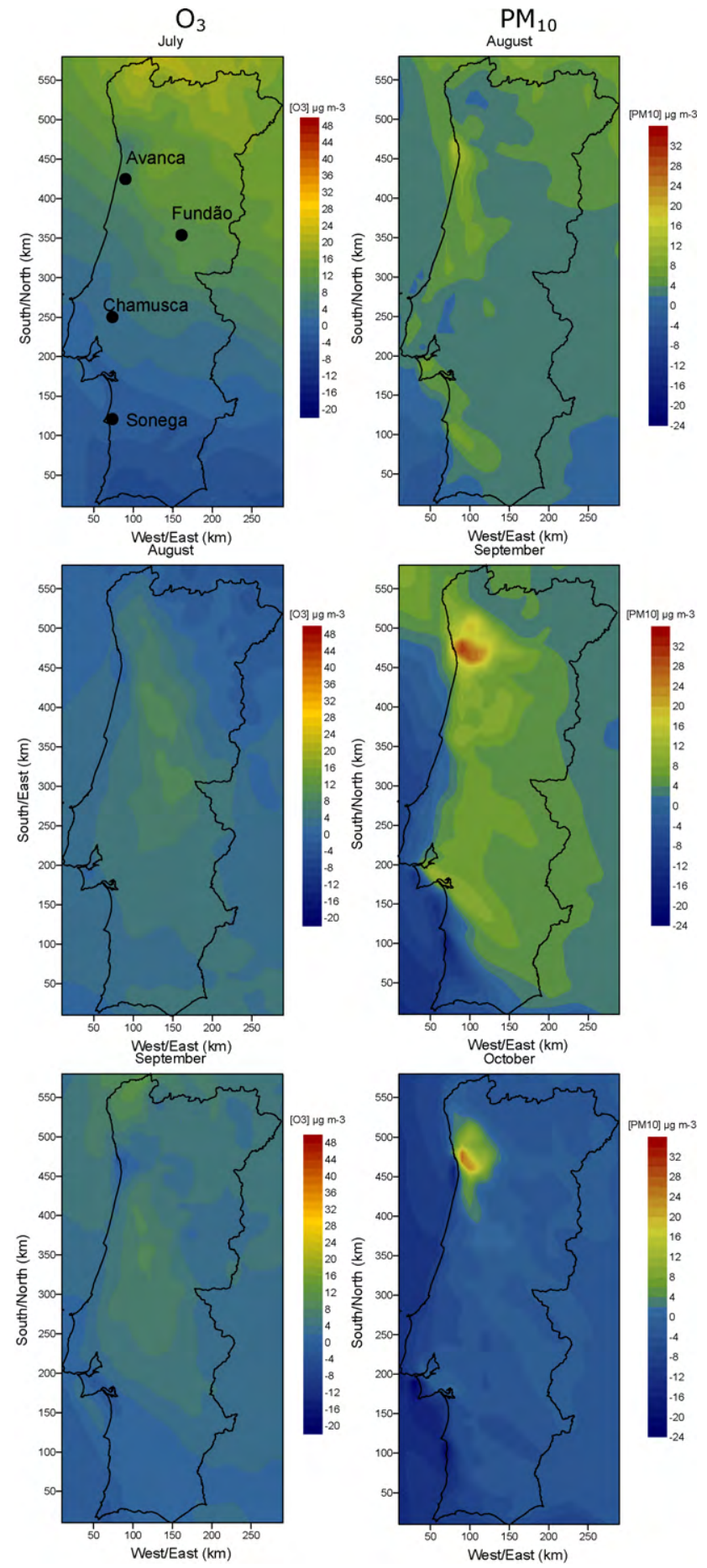

Fig. 4 - Monthly mean surface $\mathrm{O}_{3}$ and PM10 concentration changes $\left(\mu \mathrm{g} \mathrm{m}^{-3}\right)$ simulated for Portugal, only considering climate change from July to October.

over Portugal at the larger (Fig. 2) and fine scale simulations (Fig. 4), especially for September. This fact shows how important the dynamical downscaling approach may become when we are dealing with primary pollutants for which the local/regional conditions are essential. In addition, the use of high resolution emission inventory has a fundamental role in the simulated air pollutant patterns. 

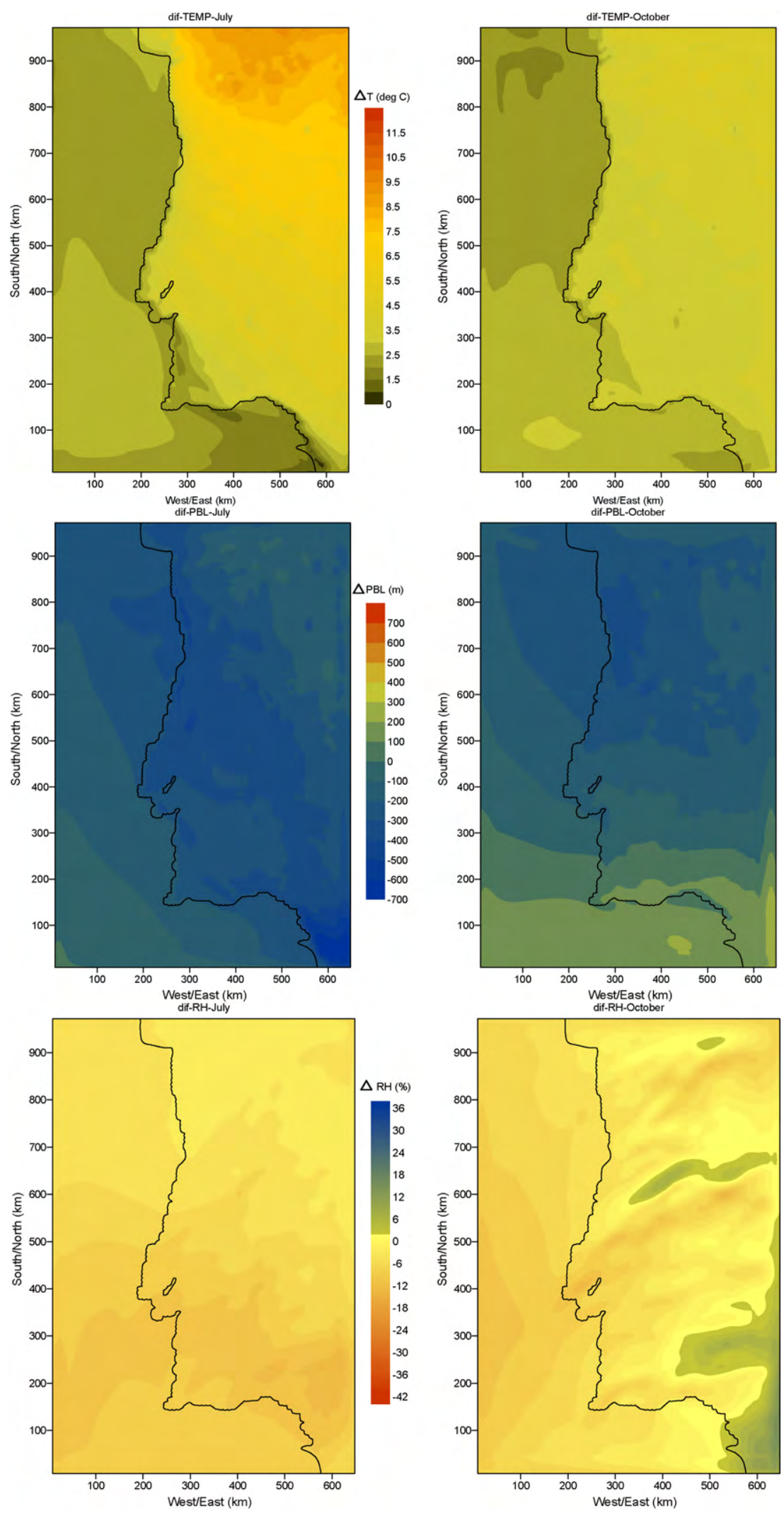

Fig. 5 - Monthly mean surface temperature $\left({ }^{\circ} \mathrm{C}\right)$, boundary layer height $(\mathrm{m})$, and relative humidity $(\%)$ differences for the climates simulation between the years 2100 and 1990 with the MM5 model for Portugal in July and October. 
Regarding $\mathrm{O}_{3}$, Fig. 4 also depicts Portugal's monthly average $\mathrm{O}_{3}$ concentration changes from July to September. The interaction between the emitted pollutants and the overall chemical reactions in the atmosphere resulting from climate change may lead to increases and decreases of ozone values depending on the region and the month. The highest increase in $\mathrm{O}_{3}$ concentrations were detected in July, but this result is clearly influenced by the air quality boundary conditions in the north of Portugal imposed by the European domain (Fig. 2). The influence of the boundary conditions is also detectable in the Southern part of the domain. In July, there was an increase in $\mathrm{O}_{3}$ levels of approximately $23 \mu \mathrm{g} \mathrm{m}^{-3}$ in the north and central regions of Portugal, caused by climate change. In August and September, the $\mathrm{O}_{3}$ concentrations registered an increase of almost 10 and $12 \mu \mathrm{g} \mathrm{m}^{-3}$, respectively. From Fig. 4 , it is possible to see that these increases are mainly located in the central part of Portugal.

The monthly analysis of the average $\mathrm{O}_{3}$ patterns over Portugal allow verifying that climate change alone may significantly impact the pollutant levels in the atmosphere, especially in July and August. The projected temperature increases has different consequences related to the pollution levels because both (a) the rates of the chemical reactions depend on the temperature and (b) the amount of biogenic VOC emissions is increasing when the temperature is increasing (Simpson et al., 1995). The impacts of climate change on the BL height and relative humidity may also influence the obtained ozone concentration patterns (Fig. 5). Miranda et al. (2005) have already detected that for specific atmospheric conditions (average daily temperature above $25^{\circ} \mathrm{C}$ ) and for some regions over Portugal, the ozone concentrations would increase approximately $14 \mu \mathrm{g} \mathrm{m}^{-3}$ from 1990 to 2050 under the IS92 scenario (Leggett et al., 1992). Although these studies are not directly comparable both indicate an increase in the average ozone levels over Portugal.

With the aim of assessing the impact of climate change on hourly $\mathrm{O}_{3}$ concentrations at rural sites, a detailed analysis was performed at four locations (see Fig. 4) distributed over Portugal that are representative of rural background conditions. Fig. 6 presents the hourly ozone concentrations between May and October for the reference and future climatic conditions.

Fig. 6a shows an increase in the 90th percentile of the hourly $\mathrm{O}_{3}$ values at all analysed stations due to the impact of climate change. The observed changes indicate how climate change may impact the peak $\mathrm{O}_{3}$ concentrations. The impact of climate change on the ozone background values is an important issue for air quality management. The 10th percentile of the hourly $\mathrm{O}_{3}$ concentrations does not reveal any changes from reference values to future climate.

For the monthly distribution of the ozone hourly values (Fig. 6b), it is possible to see that July, August, and September present the highest changes in the 90th percentile of ozone concentrations. These are the months with the highest photochemical production, which may be enhanced under future climate conditions. It is also important to note that during these months there is a clear increase on the maximum values (except in May and June).
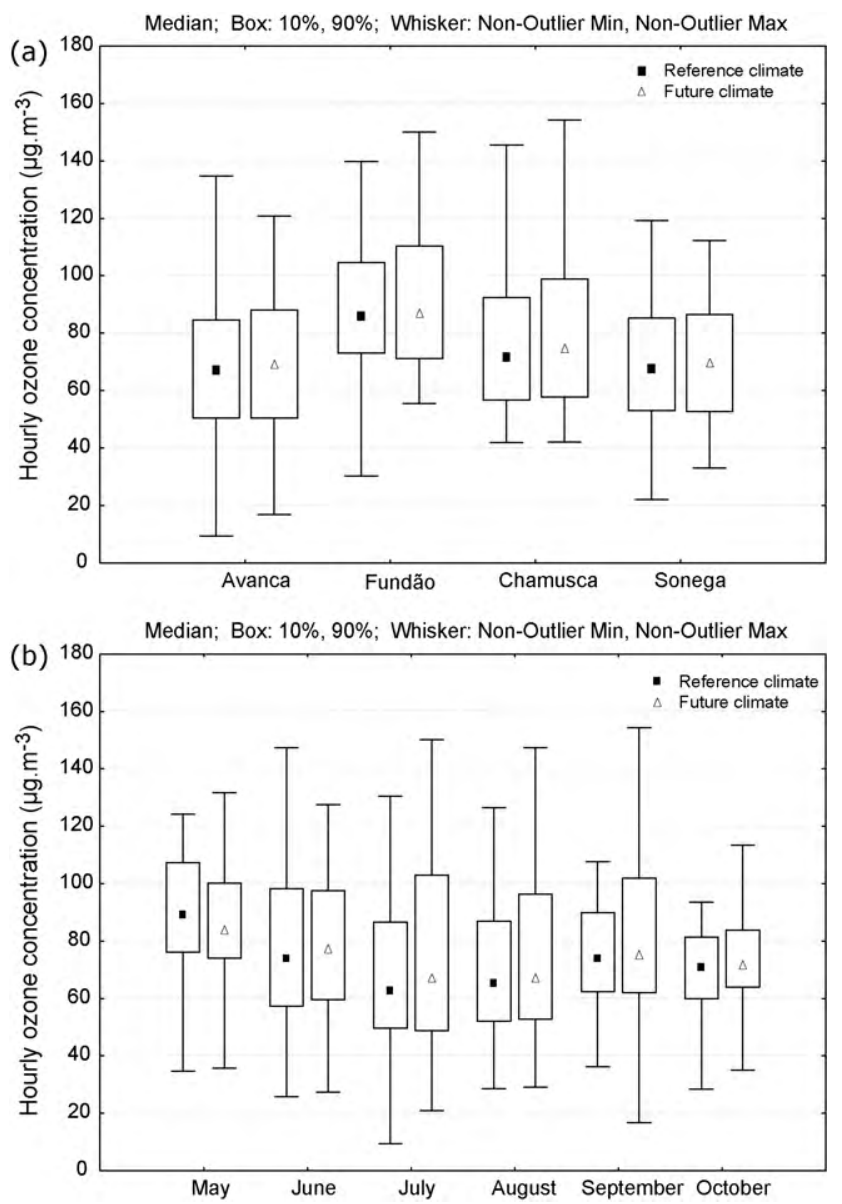

Fig. 6 - Hourly ozone concentrations $\left(\mu \mathrm{g} \mathrm{m}^{-3}\right)$ for reference (square symbol) and future climate (triangle symbol) between May 1st and October 30th by: (a) air quality station and (b) month.

In order to analyse the impact of climate change on the limit and threshold air quality values, the monthly cumulative distribution functions have been estimated for the overall simulation domain (Fig. 7). The 50th percentile of the $\mathrm{O}_{3}$ hourly values almost stays the same between the reference and the future climate. The difference between the cumulative distributions for both climates is more pronounced above the 75th percentile. The maximum values will also suffer a substantial increase namely in September $\left(+45 \mu \mathrm{g} \mathrm{m}^{-3}\right)$.

Fig. 7 also shows the cumulative distribution of the PM10 daily averages for both climate scenarios and the entire domain. The months of August, September, and October exhibit the largest changes. For the future climate, the 98th and 99th percentile will exceed the daily average PM10 limit value $\left(50 \mu \mathrm{g} \mathrm{m}^{-3}\right)$ in September and October. For the months of September and October, the range of values between the 50th percentile and the 99th percentile will significantly increase in future climate. The implications of these impacts on the fulfilment of the national and European air quality standards should constitute a matter of great concern for policy makers, environment agencies and the general public. 

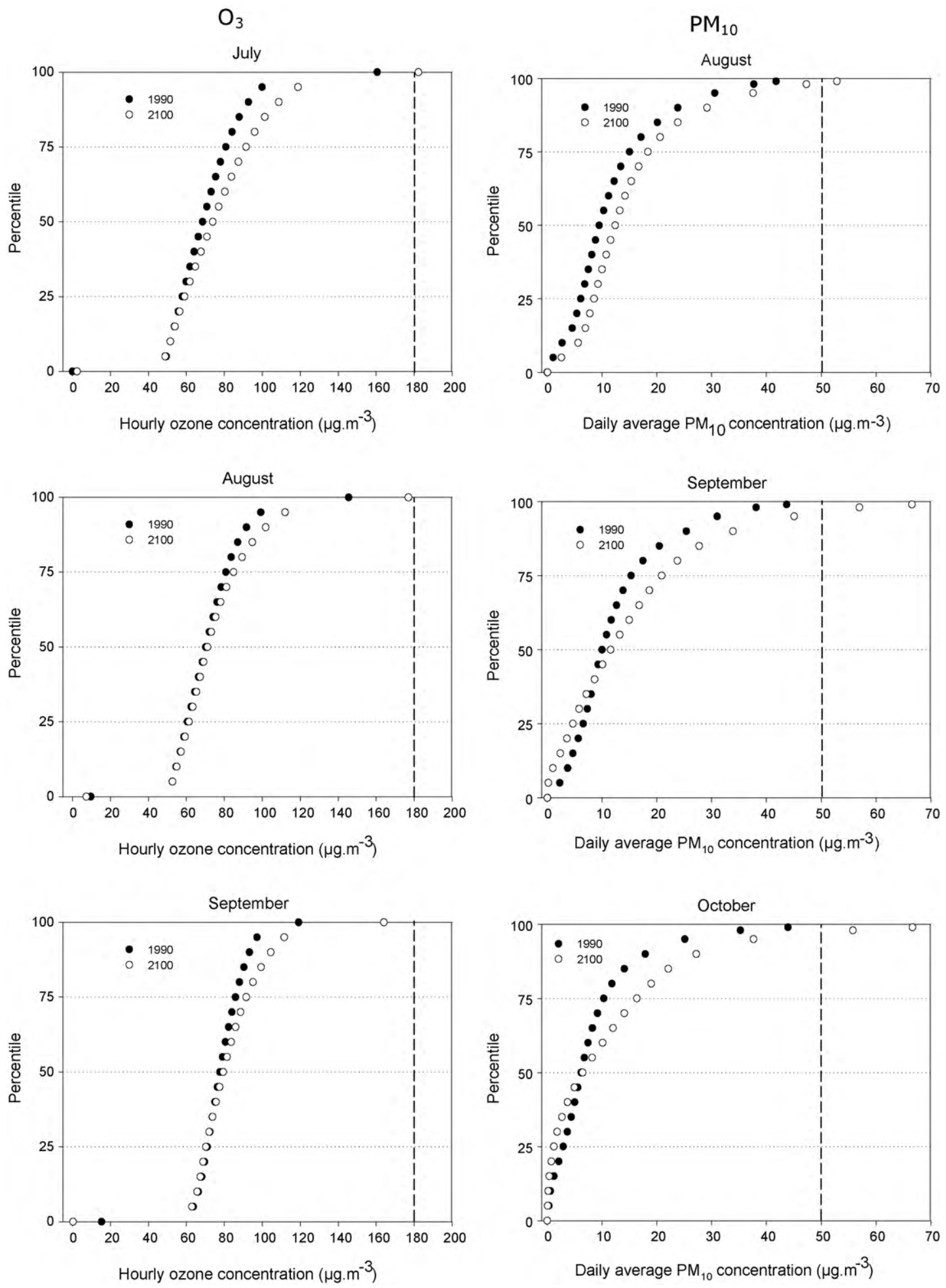

Fig. 7 - Monthly cumulative distributions of the hourly $\mathrm{O}_{3}$ concentrations and the daily average PM10 concentrations $\left(\mu \mathrm{g} \mathrm{m}^{-3}\right.$ ) for reference (black bullets) and future (open bullets) climate scenarios. The legislated limit value is indicated by the vertical dashed line (Directive 2008/50/EC).

\section{Summary and conclusions}

The main goal of this study was to investigate the impact of climate change on air quality in Portugal under the IPCC SRES A2 scenario. Numerical simulations performed with the MM5/
CHIMERE modelling system over Europe and over Portugal indicated considerable changes in the atmospheric $\mathrm{O}_{3}$ and PM10 concentrations under the SRES A2 climatic scenario.

For the future IPCC SRES A2 scenario $\mathrm{O}_{3}$ monthly mean levels in the atmosphere may increase by almost $50 \mu \mathrm{g} \mathrm{m}^{-3}$ in 
Europe in July. This estimate only considers the impact of climate change since the anthropogenic emissions were kept constant. In Portugal, in July, this increase may reach $20 \mu \mathrm{g} \mathrm{m}^{-3}$. The PM10 levels in the atmosphere will also be deeply impacted, depending on the region and the month. Throughout Portugal, the maximum increases are foreseen for the northern costal region in September reaching almost $30 \mu \mathrm{g} \mathrm{m}^{-3}$.

The forecasted changes obtained for Portugal based on the modelling application over the European domain (at $50 \mathrm{~km}$ resolution) and over Portugal (at $10 \mathrm{~km}$ resolution) highlight the importance of this type of studies at higher spatial resolutions. Fine grid resolution results are different from the coarser resolution outputs showing the need of this type of dynamical downscaling approach for impact assessment studies namely in what concerns air quality.

Based on the analysis of the hourly $\mathrm{O}_{3}$ and daily PM10 concentrations between May 1st and October 30th in Portugal, increases in the maximum values can be expected by the end of the 21st century. This trend provides important information regarding the obligation to accomplish the national and European air quality standards. It also points out the urgent need to institute measures aimed at decreasing precursor ozone emissions and PM10 emissions in order to reduce the peak ozone and PM10 values, but also to take background conditions into account.

Overall, climate change alone may deeply impact the $\mathrm{O}_{3}$ and the PM10 levels in the atmosphere. The changes in the meteorological variables that are mostly related to the advection and transformation of these pollutants impact their atmospheric concentrations. Thus, emission changes should not be the only variable to take into consideration in this kind of study. The changes in the boundary layer height, relative humidity, temperature, solar radiation, wind speed and precipitation may be responsible for significant differences in pollutant concentration patterns. In the scope of the air quality management for next decades it is necessary to include climate change and changes in climate variability when defining long-term plans and measures to improve the quality of the air we are breathing. All the forecasted changes in the pollutant concentrations must be viewed as trend indicators due to the uncertainty inherent to this type of study. In addition, the lack of scaled emissions based on the IPCC SRES A2 scenario also bounds the main findings of this study.

\section{Acknowledgements}

The authors thank the Portuguese Foundation for Science and Technology for the PhD grant of A. Carvalho (SFRH/BD/10882/ 2002) and David Hein at the Met Office Hadley Centre, U.K., for the HadAM3P climate simulations. The support from the ACCENT Network of Excellence (GOCE/CT/2004/505337) and the EU-COST 728 Action are also acknowledged.

\section{RE F E RENCES}

Anagnostopoulou, C.H.R., Tolika, K., Maheras, P., Kutiel, H., Flocas, H.A., 2008. Performance of the general circulation HadAM3P model in simulating circulation types over the
Mediterranean region. International Journal Climatology 28 (2), 185-203.

Anderson, H.R., Atkinson, R., Peacock, J., Marston, L., Konstantinou, K., 2004. Meta-analysis of Time Series Studies and Panel Studies of Particulate Matter (PM) and Ozone $\left(\mathrm{O}_{3}\right)$. Report of a WHO Task Group. WHO Regional Office for Europe, Copenhagen.

Aquilina, N., Dudek, A.V., Carvalho, A., Borrego, C., Nordeng, T.E., 2005. MM5 high resolution simulations over Lisbon. In: Geophysical Research Abstracts 2005, vol. 7, 08685, SRef-ID: 1607-7962/gra/EGU05-A-08685. European Geosciences Union.

Bessagnet, B., Hodzic, A., Vautard, R., Beekmann, M., Cheinet, S., Honore, C., Liousse, C., Rouil, L., 2004. Aerosol modeling with CHIMERE-preliminary evaluation at the continental scale. Atmospheric Environment 38, 2803-2817.

Boo, K., Kwon, W., Oh, J., Baek, H., 2004. Response of global warming on regional climate change over Korea: An experiment with the MM5 model. Geophysics Research Letters 31 , doi:10.1029/2004GL021171 L21206.

Borrego, C., Monteiro, A., Ferreira, J., Miranda, A.I., Costa, A.M., Carvalho, A.C., Lopes, M., 2008. Procedures for estimation of modelling uncertainty in air quality assessment. Environmental International, doi:10.1016/ j.envint.2007.12.005.

Carvalho, A.C., Carvalho, A., Gelpi, I., Barreiro, M., Borrego, C., Miranda, A.I., Perez-Munuzuri, V., 2006. Influence of topography and land use on pollutants dispersion in the Atlantic Coast of Iberian Peninsula. Atmospheric Environment 40 (21), 3969-3982.

Carvalho, A., Monteiro, A., Ribeiro, I., Tchepel, O., Miranda, A.I., Borrego, C., Saavedra, S., Souto, J.A., Casares, J.J., 2010. High ozone levels in the Northeast of Portugal: analysis and characterization. Atmospheric Environment 44 (8), 10201031.

Comrie, A.C., 1996. An all-season synoptic climatology of air pollution in the US-Mexico border region. Professional Geographer 48 (3), 237-251.

Dentener, F., Stevenson, D., Ellingsen, K., van Noije, T., Schultz, M., Amann, M., et al., 2006. The global atmospheric environment for the next generation. Environmental Science and Technology 40, 3586-3594.

Dudhia, J., 1993. A nonhydrostatic version of the PennState/ NCAR mesoscale model: validation tests and simulation of an Atlantic cyclone and clod front. Monthly Weather Review 121, 1493-1513.

EMEP (European Monitoring and Evaluation Programme), 2007. Transboundary particulate matter in Europe: status report 2007. Status report 4/2007: Joint CCC \& MSC-W Report.

Fernández, J., Montávez, J.P., Sáenz, J., González-Rouco, J.F., Zorita, E., 2007. Sensitivity of the MM5 mesoscale model to physical parameterizations for regional climate studies: annual cycle. Journal Geophysics Research 112 , doi:10.1029/ 2005JD006649 D04101.

Gauss, M., Myhre, G., Isaksen, I.A., Grewe, V., Pitari, G., Wild, O., et al., 2006. Radiative forcing since preindustrial times due to ozone change in the troposphere and the lower stratosphere. Atmospheric Chemistry and Physics 6, 575-599.

GENEMIS (Generation and Evaluation of Emission Data), 1994. EUROTRAC Annual Report-1993. Part 5. EUROTRAC International Scientific Secretariat, GarmischPartenkirchen.

Ginoux, P., Chin, M., Tegen, I., Prospero, J.M., Holben, B., Dubovik, O., Lin, S.J., 2001. Sources and distributions of dust aerosols simulated with the GOCART model. Journal of Geophysical Research 106, 20255-20273.

Giorgi, F., Meleux, F., 2007. Modeling the regional effects of climate change on air quality, C. R. Geoscience 339 (11-12), 721-733. 
Gordon, C., Cooper, C., Senior, C.A., Banks, H., Gregory, J.M., Johns, T.C., Mitchell, J.F.B., Wood, R.A., 2000. The simulation of SST, sea ice extents and ocean heat transports in a version of the Hadley Centre coupled model without flux adjustments. Climate Dynamics 16, 147-168.

Goswami, E., Larson, T., Lumley, T., Liu, L., 2002. Spatial characteristics of fine particulate matter: identifying representative monitoring locations in Seattle, Washington. Journal Air Waste Management 52 (3), 324-333.

Grell, G.A., Dudhia, J., Stauffer, D.R., 1994. A description of the fifth-generation Penn State/NCAR Mesoscale Model (MM5), NCAR Tech. Note, NCAR/TN-398+STR, 122 pp.

Guelle, W., Balkanski, Y.J., Dibb, J.E., Dchulz, M., Dulac, F., 1998. Wet deposition in a global size-dependent aerosol transport model. Journal Geophysics Research 103 (D22), 28875-28891.

Gustafson, W.I., Leung, L.R., 2007. Regional downscaling for air quality assessment. A reasonable proposition? Bulletin American Meteorology Society 1215-1227, doi:10.1175/ BAMS-88-8-1215.

Hansen, M.C., DeFries, R.S., Townsend, J.R., Sohlberg, R., 2000. Global land cover classification at $1 \mathrm{~km}$ spatial resolution using a classification tree approach. International Journal Remote Sensing 21 (6,7), 1331-1364.

Hauglustaine, D.A., Lathiere, J., Szopa, S., Folberth, G.A., 2005. Future tropospheric ozone simulated with a climatechemistry-biosphere model. Geophysics Research Letters 32, L24807, doi:10.1029/2005GL024031.

Hogrefe, C., Biswas, J., Lynn, B., Civerolo, K., Ku, J.Y., Rosenthal, J., et al., 2004. Simulating regional-scale ozone climatology over the eastern United States: model evaluation results. Atmospheric Environment 38, 2627-2638.

IPCC (Intergovernmental Panel on Climate Change), 2001. In: Houghton, J.T., Ding, Y., Griggs, D.J., Noguer, M., van der Linden, P.J., Dai, X., Maskell, K., Johnson, C.A. (Eds.), Climate Change 2001: The Scientific Basis. Contribution of Working Group I to the Third Assessment Report of the Intergovernmental Panel on Climate Change. Cambridge University Press, Cambridge, United Kingdom; New York, NY, USA.

IPCC (Intergovernmental Panel on Climate Change), 2007. In: Solomon, S., Qin, D., Manning, M., Chen, Z., Marquis, M., Averyt, K.B., Tignor, M., Miller, H.L. (Eds.), Climate Change 2007: The Physical Science Basis. Contribution of Working Group I to the Fourth Assessment Report of the Intergovernmental Panel on Climate Change. Cambridge University Press, Cambridge.

Jones, R., Murphy, J., Hassell, D., Taylor, R., 2001. Ensemble Mean Changes in a Simulation of the European Climate of 2071-2100 using the new Hadley Centre Regional Modelling System HadAM3H/HadRM3H. Met Office, Exeter, UK.

Jones, R.G., Murphy, J.M., Hassel, D.C., Woodage, M.J., 2005. A High Resolution Atmospheric GCM for the Generation of Regional Climate Scenarios. Hadley Center Technical Note 63. Met Office, Exeter, UK.

Jones, T.C., Gregory, J.M., Ingram, W.J., Johnson, C.E., Jones, A., Lowe, J.A., et al., 2003. Anthropogenic climate change for 1860-2100 simulated with the HadCM3 model under updated emissions scenarios. Climate Dynamics 20, 583-612.

Kalnay, E., Kanamitsu, M., Kistler, R., Collins, W., Deaven, D., Gandin, L., et al., 1996. The NCEP/NCAR 40-years reanalysis project. Bulletin American Meteorology Society 77, 437-471.

Keyes, D., Anderson, D., McKaughan, C., Eyrich, H., 2001. Estimating the costs of violating air quality standards. Environmental Monitoring Assessment 68 (1), 22-30.

Kunkel, K.E., Huang, H.-C., Liang, X.-Z., Lin, J.-T., Wuebbles, D., Tao, Z., et al., 2007. Sensitivity of future ozone concentrations in the northeast USA to regional climate change. Mitigation and Adaptation Strategies for Global Change 597-606, doi:10.1007/s11027-007-9137-y.
Langner, J., Bergström, R., Foltescu, V., 2005. Impact of climate change on surface ozone and deposition of sulphur and nitrogen in Europe. Atmospheric Environment 39, 11291141.

Leggett, J., Pepper, W.J., Swart, R.J., 1992. Emissions scenarios for IPCC: an update. In: Houghton, J.T., Callander, B.A., Varney, S.K. (Eds.), Climate Change 1992. The Supplementary Report to the IPCC Scientific Assessment. Cambridge University Press, Cambridge.

Leung, L., Ghan, S., 1999. Pacific northwest climate sensitivity simulated by a regional climate model driven by a GCM. Part I: control simulations. Journal of Climate 12 (7), 2010-2030.

Leung, L., Zhong, S., Qian, Y., Liu, Y., 2004. Evaluation of regional climate simulations of the 1998 and 1999 east Asian summer monsoon using the GAME/HUBEX observational data. Journal of the Meteorological Society of Japan 82 (6), 1695-1713.

Mearns, L.O., Giorgi, F., Whetton, P., Pabon, D., Hulme, M., Lal, M., 2003. Guidelines for Use of Climate Scenarios Developed from Regional Climate Model Experiments. DDC of IPCC TGCIA, Final Version.

Meleux, F., Solmon, F., Giorgi, F., 2007. Increase in summer European ozone amounts due to climate change. Atmospheric Environment 41, 7577-7587.

Middleton, P., Stockwell, W.R., Carter, W.P.L., 1990. Aggregation and analysis of volatile organic compound emissions for regional modeling. Atmospheric Environment 24A, 11071133.

Miranda, A.I., Carvalho, A.C., Martins, H., Carvalho, A., Rocha, A., Borrego, C., 2005. Climate change impacts on air quality over Portugal. In: Sohki, R. (Ed.), 5th International Conference on Urban air quality, 29-31 March, Valencia, Espanha.

Monteiro, A., Vautard, R., Borrego, C., Miranda, A.I., 2005. Longterm simulations of photo oxidant pollution over Portugal using the CHIMERE model. Atmospheric Environment 39, 3089-3101.

Monteiro, A., Miranda, A.I., Borrego, C., Vautard, R., Ferreira, J., Perez, A.T., 2007. Long-term assessment of particulate matter using CHIMERE model. Atmospheric Environment 41, 7726-7738.

Nenes, A., Pandis, S.N., Pilinis, C., 1999. Continued development and testing of a new thermodynamic aerosol module for urban and regional air quality models. Atmospheric Environment 33, 1553-1560.

New, M., Lister, D., Hulme, M., Makin, I., 2002. A high-resolution data set of surface climate over global land areas. Climate Research 21, 1-25.

Pio, C., Legrand, M., Oliveira, T., Afonso, A., Santos, C., Caseiro, A., Fialho, P., Barata, F., Puxbaum, H., Sanchez-Ochoa, A., Kasper-Gielb, A., Gelencser, A., Preunkert, S., Schock, M., 2007. Climatology of aerosol composition (organic versus inorganic) at non-urban areas on a West-East transect across Europe. Journal of Geophysics Research 112 (D23), S02, doi:10.1029/2006JD008038.

Pope, V.D., Gallani, M.L., Rowntree, P.R., Stratton, R.A., 2000. The impact of new physical parametrizations in the Hadley Centre climate model: HadAM3. Climate Dynamics 16, 123-146.

Prather, M., Gauss, M., Berntsen, T., Isaksen, I., Sundet, J., Bey, I., et al., 2003. Fresh air in the 21st century. Geophysical Research Letters 30 (2), doi:10.1029/2002GL016285.

Rowell, D.P., 2005. A scenario of European climate change for the late twenty-first century: seasonal means and interannual variability. Climate Dynamics 25, 837-849.

Schmidt, H., Derognat, C., Vautard, R., Beekmann, M., 2001. A comparison of simulated and observed ozone mixing ratios for the summer of 1998 in Western Europe. Atmospheric Environment 35 (36), 6277-6297. 
Semazzi, F., 2003. Air quality research: perspective from climate change modelling research. Environment International 29, 253-261.

Sillman, S., Samson, P.J., 1995. Impact of temperature on oxidant photochemistry in urban, polluted rural and remote environments. Journal Geophysics Research 100, 1149711508.

Simpson, D., Guenther, A., Hewitt, C.N., Steinbrecher, R., 1995. Biogenic emissions in Europe. 1- Estimates and uncertainties. Journal of Geophysical Research 100, 2287522890.

Simpson, D., Winiwarter, W., Borjesson, G., Cinderby, S., Ferreiro, A., Guenther, A., et al., 1999. Inventorying emissions from nature in Europe. Journal Geophysics Research 104 (D7), 8113-8152.

Solman, S., Nuñez, M., Cabré, M.F., 2007. Regional climate change experiments over southern South America. I: present climate. Climate Dynamics, doi:10.1007/s00382007r-r0304-3.

Stern, R., Builtjes, P., Schaap, M., Timmermans, R., Vautard, R., Hodzic, A., Memmesheimer, M., Feldmann, H., Renner, E., Wolke, R., Kerschbaumer, A., 2008. A model intercomparison study focussing on episodes with elevated PM10 concentrations. Atmospheric Environment 42, 4567-4588.

Stohl, A., Williams, E., Wotawa, G., Kromp-Kolb, H., 1996. A European inventory for soil nitric oxide emissions and the effect of these emissions on the photochemical formation of ozone. Atmospheric Environment 30, 374-3755.

Szopa, S., Hauglustaine, D.A., Vautard, R., Menut, L., 2006. Future global tropospheric ozone changes and impact on European air quality. Geophysics Research Letters 33 , doi:10.1029/2006GL025860 L14805.

Van Dijck, S., Laouina, A., Carvalho, A., Loos, S., Schipper, A., Kwast, H., et al., 2005. Desertification in Northern Morocco due to effects of climate change on groundwater recharge $<$ / CT>. In: Kepner, W., Rubio, J., Mouat, D., Pedrazzini, F. (Eds.), Desertification in the Mediterranean Region. A Security Issue. Springer, New York, ISBN: 1-4020-3758-9.

Vautard, R., Bessagnet, B., Chin, M., Menut, L., 2005. On the contribution of natural Aeolian sources to particulate matter concentrations in Europe: testing hypotheses with a modelling approach. Atmospheric Environment 39 (18), 3291-3303.

Vautard, R., Builtjes, P., Thunis, P., Cuvelier, K., Bedogni, M., Bssagnet, B., Honoré, C., Moussiopoulos, N., Schaap, M., Stern, R., Tarrason, L., van Loon, M., 2007. Evaluation and intercomparison of Ozone and PM10 simulations by several chemistry-transport models over 4 European cities within the City-Delta project. Atmospheric Environment 41, 173-188.

Vestreng, V., 2003. Review and revision of emission data reported to CLRTAP. EMEP Status Report.

Vukovich, F.M., Sherwell, J., 2003. An examination of the relationship between certain meteorological parameters and surface ozone variations in the Baltimore-Washington corridor. Atmospheric Environment 37, 971-981.

Wise, E., Comrie, A., 2005. Meteorologically adjusted urban air quality trends in the Southwestern United States. Atmospheric Environment 39, 2969-2980.
Zlatev, Z., 2007. Comprehensive air pollution studies by the Danish Eulerian Model. Air, water and soil quality modelling for risk and impact assessment. In: Ebel, A., Davitashvili, T. (Eds.), Nato Science for Peace and Security Series C - Environmental Security, 293-302.

Anabela Carvalho has a $\mathrm{PhD}$ in environmental applied sciences. She has an MSc on management and environmental policies and a degree on environmental engineering. Currently, she is a member of the Research Group on Emissions, Modelling and Climate Change (GEMAC). Her research interests include climate change, forest fires emissions and air quality modelling. She has participated in several international (EC funded) and national research projects.

Alexandra Monteiro is currently a researcher and an Invited Professor at the Department of Environment of the University of Aveiro. She has a PhD in Sciences Applied to the Environment at the University of Aveiro, a Master of Science degree in Atmospheric Pollution and a degree in Chemical Engineering. She is a member of the Research Group on Emissions, Modelling and Climate Change (GEMAC). Her research interests include regional and urban air quality, air quality forecasting, air pollution (emissions and modelling), forest fire emissions and pollution health effects.

Silvina Solman was awarded a PhD in Atmospheric Sciences at the University of Buenos Aires, Argentina in 1993. She has been a Professor in the Department of Atmospheric Sciences, University of Buenos Aires since 2006. She has held a Permanent Research Position at Consejo Nacional de Investigaciones Científicas y Técnicas (CONICET), Argentina since 2000. Her research topics are mainly focused on regional climate variability over South America, regional climate modelling, climate change, regional scenarios of climate change (statistical and dynamical downscaling).

Ana Isabel Miranda is an associate professor at the University of Aveiro. She received her $\mathrm{PhD}$ on environmental applied sciences, as well as a degree in environmental engineering, from the University of Aveiro in 1998 and 1989, respectively. She is co-coordinating the Research Group on Emissions, Modelling and Climate Change. She has published over 150 scientific journal and conference papers. She participated in several national and European research projects coordinating three national research projects and scientifically leading from the University of Aveiro one European project in the areas of air pollution and forest fires.

Carlos Borrego is full professor of environmental engineering, with focus on air pollution and environment. He has the habilitation on environmental applied sciences from the University of Aveiro, PhD and MSc from the Free University of Brussels and a degree in mechanical engineering from the Technical University of Lisbon. He was the Chairman of the Scientific Board of the International Technical Meetings of NATO-CCMS on Air Pollution Modelling and its Application between 2001 and 2007and was vicechairman of the Environmental Assessment Group of EUROTRAC2 (EUREKA Environmental Project), from 1997 to 2000. He has been the scientific co-ordinator of several projects under the FP of EC Environment and Sustainable Development Programme and under the National Funding Agency. 